\title{
4-Toluene Sulfonate Methyl-Monooxygenase from Comamonas testosteroni T-2: Purification and Some Properties of the Oxygenase Component
}

\author{
HANS H. LOCHER, THOMAS LEISINGER, AND ALASDAIR M. COOK* \\ Microbiology Institute, Swiss Federal Institute of Technology, \\ ETH-Zentrum, CH-8092 Zürich, Switzerland
}

\begin{abstract}
Comamonas testosteroni T-2 synthesizes an inducible enzyme system that oxygenates 4-toluene sulfonate (TS) to 4-sulfobenzyl alcohol when grown in TS-salts medium. We purified this TS methyl-monooxygenase system (TSMOS) and found it to consist of two components. A monomeric, iron-sulfur flavoprotein (component B), which has been shown to act as a reductase in the 4-sulfobenzoate dioxygenase system of this organism $(\mathrm{H}$. $\mathrm{H}$. Locher, T. Leisinger, and A. M. Cook, Biochem. J. 274:833-842, 1991), carried electrons from NADH to component $M$, an oxygenase. This oxygenase had the UV-visible spectral characteristics of an iron-sulfur protein. $M_{r} s$ of about 152,000 for the native oxygenase and of 43,000 under denaturing conditions indicated a homotri- or homotetrameric enzyme, whose $\mathbf{N}$-terminal amino acids and amino acid composition were determined. The activity of the purified enzyme was enhanced about fivefold by the addition of $\mathrm{Fe}^{2+}$. In the presence of $\mathrm{O}_{2}$ and NADH, components $B$ and $M$ together catalyzed the stoichiometric transformation of TS or $p$-toluate to the corresponding alcohol. The reaction was confirmed as oxygenation of the methyl group by observation of an oxygen atom from ${ }^{18} \mathrm{O}_{2}$ in carboxybenzyl alcohol. The substrate range of TSMOS included carboxylated analogs of TS ( $p$ - and $m$-toluates and 4-ethylbenzoate), whereas $p$-xylene, toluene, and $p$-cresol were not substrates. TSMOS also catalyzed demethylation; 4-methoxybenzoate was transformed to 4-hydroxybenzoate and formaldehyde.
\end{abstract}

Many aromatic compounds which contain an $O$-methyl or a ring methyl group are metabolized by aerobic bacteria via the initial introduction of a hydroxy function into the methyl group $(9-11,37)$. Three types of enzyme catalyze these initial reactions. Firstly, flavin hydroxylases introduce hydroxyl groups from water into methyl groups para to hydroxyl groups ( $p$-cresol methylhydroxylases [18]; see also reference 26). Secondly, monooxygenases catalyze $O$ demethylation (4-methoxybenzoate $O$-demethylase $[5,27])$ and, as a side reaction, monooxygenation of aromatic methyl groups (3). Thirdly, monooxygenation of aromatic methyl groups is recognized. However, very little is known about the biochemistry of this third type of enzyme $(10,14,15)$, although a two-component methyl-monooxygenase system for toluene (and xylenes) has been postulated from chromatographic evidence (24) and genes for a toluene (and xylene) methyl-monooxygenase have been sequenced (32).

Comamonas testosteroni T-2 utilizes the xenobiotic compound 4-toluene sulfonate (TS) as the sole source of carbon and energy for growth $(21,33)$. TS is metabolized by oxidation of the methyl group to form 4-sulfobenzoate (PSB), which is desulfonated by the action of the PSB dioxygenase system (PSBDOS) $(21,22)$ (Fig. 1). The introduction of the hydroxyl group to form 4-sulfobenzyl alcohol in crude extracts was dependent on the presence of NADH and stoichiometric amounts of $\mathrm{O}_{2}$, and a monooxygenase reaction was postulated (21). We recently reported the purification and characterization of the desulfonative, twocomponent PSBDOS of $C$. testosteroni T-2 (22). When the reductase (component $B$ or reductase $B$ ) of this system was

\footnotetext{
* Corresponding author.
}

combined with a distinct fraction from an anion-exchange column, TS monooxygenase activity was obtained.

We now report the purification and some properties of the oxygenase (component $M$ or oxygenase $M$ ) of this twocomponent enzyme system, which we term the TS methylmonooxygenase system (TSMOS).

\section{MATERIALS AND METHODS}

Materials. $p$-Xylene, $p$-cresol, toluates, 4-ethylbenzoate, 4-methoxybenzoate, trifluoroacetate, and Ponceau $S$ red were from Fluka, Buchs, Switzerland. 4-Carboxybenzyl alcohol was from Sigma Chemical Co., St. Louis, Mo. ${ }^{18} \mathrm{O}_{2}$ (97\% enrichment) was obtained from Medgenix $\mathrm{GmbH}$, Düsseldorf, Germany. Beef liver catalase was from Boehringer GmbH, Mannheim, Germany. The sources of other chemicals and of materials for protein purification are given elsewhere $(21,22,33)$.

Analytical methods. Substrate turnover was monitored by high-pressure liquid chromatography (HPLC) on reversedphase columns (21); UV spectra were recorded in a diode array detector. Products for analysis by mass spectrometry (MS) were preseparated in $0.1 \%$ ( $\mathrm{vol} / \mathrm{vol}$ ) aqueous trifluoroacetic acid containing appropriate amounts of methanol. Positive chemical ionization (PCI) mass spectra were measured in a quadrupole MS (model 4500; Finnigan, San Jose, Calif.) with a direct-exposure probe. The energy setting was $40 \mathrm{eV}$, and methane was used as the reagent gas. Electron impact (EI) mass spectra were obtained on a particle beam HPLC-MS (Hewlett-Packard, Palo Alto, Calif.) (36). Samples were separated on Nucleosil-C18 reversed-phase columns $(2.1$ by $100 \mathrm{~mm})$ with an eluent consisting of $0.5 \%$ ( $\mathrm{vol} / \mathrm{vol})$ formic acid in water and a linear gradient of 


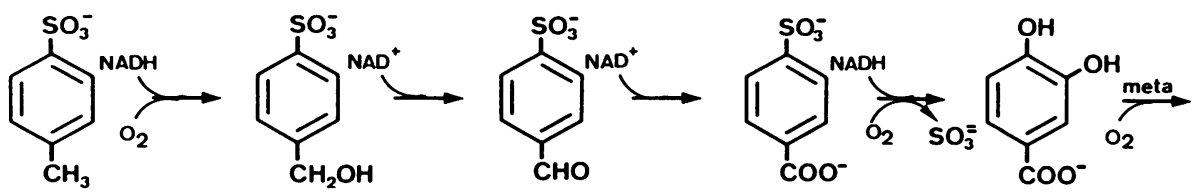

FIG. 1. Degradative pathway of TS in C. testosteroni T-2.

methanol ( 0 to $100 \%$ over $30 \mathrm{~min}$, with a flow rate of 0.2 $\mathrm{ml} / \mathrm{min}$ ). Formaldehyde was determined colorimetrically as described by Stucki et al. (30). Protein concentrations were measured by the method of Bradford (7) with bovine serum albumin as the standard.

Sodium dodecyl sulfate-polyacrylamide gel electrophoresis (SDS-PAGE) (20) was used to monitor protein purification and to estimate molecular weights under denaturing conditions. Proteins were stained with Coomassie brilliant blue $(20,22)$. The $\mathrm{N}$-terminal amino acid sequence was determined with protein bands blotted from SDS-PAGE gels onto polyvinylidene difluoride membranes and subjected to Edman degradation (22). Blotting was performed with a Mini Trans-Blot cell (Bio-Rad, Richmond, Calif.) at $50 \mathrm{~V}$ (140 to $170 \mathrm{~mA}$ ) for $1 \mathrm{~h}$ at $4^{\circ} \mathrm{C}$. The blotting buffer consisted of 25 $\mathrm{mM}$ Tris base, $190 \mathrm{mM}$ glycine, $20 \%$ (vol/vol) methanol, and $0.02 \%(\mathrm{wt} / \mathrm{vol})$ SDS. After being blotted, proteins were stained with $0.2 \%$ (wt/vol) Ponceau $\mathrm{S}$ red in $3 \%$ (vol/vol) trichloroacetetic acid. The amino acid compositions of desalted proteins were determined, and the values obtained were corrected when necessary for losses during hydrolysis (22). The $M_{\mathrm{r}}$ of the native enzyme was estimated by gel filtration through a Superose 12 column (10 by $300 \mathrm{~mm}$ ) (Pharmacia, Uppsala, Sweden) as detailed elsewhere (22).

Growth of the organism, preparation of cell extracts, and enzyme assays. $C$. testosteroni T-2 $(21,33)$ was grown in TS-, PSB-, or succinate-salts medium (22). Cells for the purification of TSMOS were obtained and stored as described elsewhere (22), except that PSB was replaced by TS. Cells were disrupted in a French pressure cell, and crude extract was prepared as described elsewhere (22). This extract could be stored at $-20^{\circ} \mathrm{C}$ for at least 4 weeks without the loss of TSMOS activity; at $4^{\circ} \mathrm{C}$ about $20 \%$ of the activity was lost over $24 \mathrm{~h}$.

TSMOS activity was routinely assayed as oxygen uptake at $30^{\circ} \mathrm{C}$ in a Clarke-type oxygen electrode with a $1-\mathrm{ml}$ reaction vessel (22). The optimized reaction mixture contained (in $0.5 \mathrm{ml}$ ) $25 \mu \mathrm{mol}$ of potassium phosphate buffer ( $\mathrm{pH}$ 7.0), $200 \mathrm{nmol}$ of $\mathrm{NADH}, 40 \mathrm{nmol}$ of $\mathrm{FeSO}_{4}$, and protein (with crude extracts, $750 \mu \mathrm{g}$, and with purified enzyme, 20 to $50 \mu \mathrm{g}$, each of oxygenase [component $\mathrm{M}$ ] and reductase [component B]), and the reaction was started by the addition of $500 \mathrm{nmol}$ of 4-ethylbenzoate (see Results for an explanation). The stoichiometry of the purified TSMOS reaction was determined as substrate disappearance and product formation by HPLC, coupled to measurements of oxygen consumption. $\mathrm{H}_{2} \mathrm{O}_{2}$ formed by uncoupling of the electron flow with some pseudosubstrates for TSMOS was detected as the liberation of oxygen upon the addition of $6,500 \mathrm{U}$ of catalase to the standard oxygen uptake assay (3). The source of the hydroxyl group in the product formed from $p$-toluate was examined in an experiment in which the enzyme assay was carried out in gas-tight $10-\mathrm{ml}$ vials containing defined atmospheres of nitrogen $(80 \%$ [vol/vol] $)$ and oxygen $(20 \%$ [vol/ vol] either ${ }^{16} \mathrm{O}_{2}$ or $\left.{ }^{18} \mathrm{O}_{2}\right)(21)$. Reaction mixtures $(2 \mathrm{ml})$ contained $100 \mu \mathrm{mol}$ of potassium phosphate buffer ( $\mathrm{pH} 7.0$ ),
$1.6 \mu \mathrm{mol}$ of $\mathrm{NADH}, 160 \mathrm{nmol}$ of $\mathrm{FeSO}_{4}$, and 50 to $100 \mu \mathrm{g}$ each of oxygenase (component $M$ ) and reductase (component B). The reaction was started by the injection of $4 \mu \mathrm{mol}$ of degassed substrate ( $p$-toluate). After $15 \mathrm{~min}$ of incubation at $30^{\circ} \mathrm{C}$ in a shaking water bath, the reaction was stopped by precipitation of the proteins with $60 \mu \mathrm{l}$ of $70 \%(\mathrm{vol} / \mathrm{vol})$ perchloric acid. Proteins were removed by centrifugation, and products in the supernatant fluid were monitored and purified by HPLC. Carboxylated products were separated from the eluent by extraction (twice) with equal volumes of diethyl ether, which was removed by evaporation, and the residues were dissolved in small volumes of $\mathrm{H}_{2} \mathrm{O}$ prior to analysis by MS.

Reductase B was identified as TSMOS activity when fractions were combined with component $\mathrm{M}$, and reductase B was assayed routinely at $25^{\circ} \mathrm{C}$ as cytochrome $c$ reduction (22).

Purification of TSMOS. The procedure for TSMOS purification is in all practical respects similar to that for PSBDOS purification (22)

(i) Step 1. Nucleic acids were removed by precipitation with protamine sulfate as described elsewhere (22).

(ii) Step 2. The anion-exchange column (16 by $100 \mathrm{~mm}$; Mono Q; Pharmacia) was equilibrated (4 ml/min) with buffer A ( $25 \mathrm{mM}$ potassium phosphate buffer $[\mathrm{pH} 7.0]$ containing 1 $\mathrm{mM}$ dithiothreitol) and loaded with the supernatant from step 1 (10 ml; $400 \mathrm{mg}$ of protein). Proteins were eluted with an increasing gradient of $\mathrm{Na}_{2} \mathrm{SO}_{4}$ (see Fig. 2), and 4-ml fractions were collected. No single fraction showed TSMOS activity, but activity was obtained when red-brown fractions M (no. 24 to 28 ) were combined with yellow fractions B (no. 34 to 38 ), which were known to contain reductase B (22). Fractions which showed TSMOS activity when combined with component $\mathrm{B}$ were pooled, and the material (crude component $\mathrm{M}$ ) was concentrated by membrane filtration (Centriprep; Amicon, Danvers, Mass.). Fractions containing reductase $B$ were pooled and purified to homogeneity as reported previously (22).

(iii) Step 3. Hydrophobic interaction chromatography was done with a phenyl-Superose column $(5$ by $50 \mathrm{~mm}$; Pharmacia). Crude component $M$ from step 2 was brought to $1 \mathrm{M}$ $\left(\mathrm{NH}_{4}\right)_{2} \mathrm{SO}_{4}$ by the addition of $3 \mathrm{M}\left(\mathrm{NH}_{4}\right)_{2} \mathrm{SO}_{4}$ and, in two separate runs, was loaded onto the column, which had been equilibrated $(0.5 \mathrm{ml} / \mathrm{min})$ with buffer $\mathrm{A}$ containing $1 \mathrm{M}$ $\left(\mathrm{NH}_{4}\right)_{2} \mathrm{SO}_{4}$. The column was rinsed for $10 \mathrm{~min}$, and the concentration of $\left(\mathrm{NH}_{4}\right)_{2} \mathrm{SO}_{4}$ was decreased to $0 \mathrm{M}$ over 50 min. Fractions of $1 \mathrm{ml}$ were collected and assayed for TSMOS activity in the coupled assay. TSMOS activity eluted in a symmetrical, well-separated peak at about 250 to $300 \mathrm{mM}\left(\mathrm{NH}_{4}\right)_{2} \mathrm{SO}_{4}$. The active fractions from both runs were pooled and concentrated.

(iv) Step 4. Component $M$ from step 3 was loaded on a gel filtration column (21.5 by $300 \mathrm{~mm}$; TSK G $3000 \mathrm{SW}$; Toyo Soda, Tokyo, Japan) equilibrated ( $3 \mathrm{ml} / \mathrm{min}$ ) with buffer A containing $150 \mathrm{mM} \mathrm{Na} \mathrm{SO}_{4}$. Samples of $1.5 \mathrm{ml}$ were collected and assayed for TSMOS activity in the coupled assay. 
TABLE 1. Purification of component M of TSMOS ${ }^{a}$

\begin{tabular}{lccccc}
\hline \multicolumn{1}{c}{ Step } & $\begin{array}{c}\text { Protein } \\
\text { (mg) }\end{array}$ & $\begin{array}{c}\text { Activity } \\
\text { (nkat) }\end{array}$ & $\begin{array}{c}\text { Sp act } \\
\text { (mkat/kg } \\
\text { of protein) }\end{array}$ & $\begin{array}{c}\text { Recovery } \\
(\%)\end{array}$ & $\begin{array}{c}\text { Purification } \\
\text { (fold) }\end{array}$ \\
\hline $\begin{array}{l}\text { Crude extract } \\
\text { Protamine sulfate }\end{array}$ & 309 & 953 & 3.08 & 100 & 1 \\
$\quad$ treatment & & 910 & 3.00 & 95.5 & 0.97 \\
Mlono Q & 18.8 & 548 & 29.1 & 57.5 & 9.5 \\
Phenyl-Superose & 4.8 & 230 & 47.9 & 24.1 & 15.6 \\
(icl filtration & 2.8 & 190 & 67.8 & 19.9 & 22 \\
\hline
\end{tabular}

TSMOS was assayed as 4-ethylbenzoate-dependent oxygen uptake in the presence of partially purified reductase $B$, such that valid specific activities were obtained, as described in Materials and Methods.

The activity eluted in a single symmetrical peak at about 25 min. The active fractions were pooled, concentrated about five times, and stored at $-20^{\circ} \mathrm{C}$ or used immediately for characterization.

\section{RESULTS}

Enzyme assay for TSMOS and specific activities. Assays for multicomponent oxygenases in crude extracts tend to display a nonlinear response to protein concentration (e.g., 1, $34)$ because of a lack of reductase $(2,22)$. The assay for TSMOS in crude extracts, however, showed an essentially linear response to protein concentration, and the addition of crude reductase B (50 to $100 \mu \mathrm{g})$ caused little alteration in rate $(<10 \%)$ or linearity. Crude extracts from TS-grown cells are therefore essentially saturated with reductase. Nevertheless, to obtain similar conditions in all assays, we always added $50 \mu \mathrm{g}$ of crude component $\mathrm{B}$. Comparison among preparations was complicated by the fact that, although the monooxygenase itself requires only $1 \mathrm{~mol}$ of $\mathrm{O}_{2}$ per mol of TS, the reaction of the crude extract with TS consumes 3 mol of $\mathrm{O}_{2}$ per mol of TS (21). Since TSMOS is more active than PSBDOS is (21), the measured oxygen uptake rates in crude extracts are less than threefold the net reaction rate with TS as the substrate. We solved this problem by exploiting the wide substrate range of TSMOS (see below) and choosing a substrate (4-ethylbenzoate) whose transformation product was not oxygenated in crude extracts. We thus had an assay system which allowed a direct comparison of valid specific activities of TSMOS among different enzyme preparations or crude extracts.

The supernatant fluid from cell extracts from $C$. testosteroni T-2 optimally grown in TS-salts medium contained highly active TSMOS (3.1 mkat/kg of protein) (Table 1) compared with extracts from PSB- and succinate-grown cells $(0.2$ and $0.01 \mathrm{mkat} / \mathrm{kg}$ of protein, respectively). This result confirms initial observations (21) that TSMOS is a soluble and inducible enzyme system. This high specific activity $(3.1 \mathrm{mkat} / \mathrm{kg}$ of protein with 4-ethylbenzoate) (Table 1) must represent about $3.9 \mathrm{mkat} / \mathrm{kg}$ of protein with TS as the substrate (see below) or about $85 \%$ of the TSMOS activity calculated to be present in growing cells (21). It seems, therefore, to be a reasonable assumption that we are examining proteins responsible for TSMOS activity in growing cells.

Purification of TSMOS. When proteins in crude extracts were separated by anion-exchange chromatography, no single fraction was active, but three colored bands were observed (red-brown regions $A$ and $M$ and yellow region $B$ ). Regions $A$ and $B$ contained the oxygenase (A) and the reductase (B) components of PSBDOS (22). TSMOS activity was obtained when regions $M$ and B were combined (Fig. 2). Purified reductase $B$ combined with fraction $M$ showed TSMOS activity, confirming that this reductase is active in both PSBDOS and TSMOS. Whereas reductase B represented about $1 \%$ of the soluble protein in earlier work (22), we found it to be present at 5 to $10 \%$ in cells optimally induced for TSMOS but only in small amounts $(<1 \%)$ in cells grown solely in PSB-salts medium.

Component $\mathbf{M}$, the putative oxygenase component of TSMOS, was purified by hydrophobic interaction chromatography and gel filtration. Only one protein peak was observed in the final step (data not shown), and essentially one band was observed upon SDS-PAGE (Fig. 3), although a frequent contaminant (about $2 \%$ ) of $M_{\mathrm{r}} 34,000$ was found. A typical purification of component $\mathbf{M}$ is shown in Table 1 . About $3 \mathrm{mg}$ of pure component $\mathbf{M}$ was obtained from about $300 \mathrm{mg}$ of soluble protein (about $8 \mathrm{~g}$ of wet cells). Assuming no significant losses of activity upon extraction and purification, component $M$ of TSMOS represented about $4.5 \%$ of the total soluble protein in strain $\mathrm{T}-2$, consistent with the density of the relevant band in crude extracts (Fig. 3).

Physical properties of component $M$ of TSMOS. The $M_{\mathrm{r}}$ of native component $\mathbf{M}$, as determined by gel filtration, was about 152,000 . Under denaturing conditions, an $M_{\mathrm{r}}$ of 43,000 was observed (Fig. 3). We presume that the native enzyme is composed of four or three subunits of identical size.

The amino acid composition of component $M$ of TSMOS is shown in Table 2. The $\mathrm{N}$-terminal amino acid sequence was Met-Phe-Ile-Ile-Asn-Asn-(Trp)-Tyr-Val-(Ala)-Ala-Ala(Asp)-Thr-X-Ile-Pro. The parentheses indicate a questionable identification. One unique sequence was obtained, indicating that the enzyme is composed of identical subunits.

The absorption spectrum of the purified enzyme showed maxima at $560 \mathrm{~nm}$ (shoulder), $462 \mathrm{~nm}$, and $330 \mathrm{~nm}$ (Fig. 4). When the enzyme was reduced by trace amounts of dithionite or by reductase $\mathrm{B}$ and $\mathrm{NADH}$, a loss of absorption at 560 and $462 \mathrm{~nm}$ was observed, and a new maximum appeared at $521 \mathrm{~nm}$. These characteristics are similar to those of other oxygenase components (Table 3), which are known $(1,2)$ or believed $(22)$ to contain a Rieske iron-sulfur center. We thus presume oxygenase $M$ of TSMOS to contain an iron-sulfur center.

Catalytic properties of TSMOS. The substrate specificity of purified TSMOS was examined in the oxygen uptake assay, and transformation of substrates was determined by HPLC. At least four methyl or ethyl aromatic compounds were substrates and subject to hydroxylation (Table 4). The reaction with $p$-toluate was also examined in the presence of ${ }^{18} \mathrm{O}_{2}$, and the PCI mass spectrum obtained from the product showed a protonated molecular ion at $\mathrm{m} / z 155\left[(\mathrm{M}+\mathrm{H})^{+}\right]$, two mass units higher than the corresponding ion obtained from the product formed in the presence of ${ }^{16} \mathrm{O}_{2}$ or from authentic $p$-carboxybenzyl alcohol. This result demonstrates the incorporation of one oxygen atom from ${ }^{18} \mathrm{O}_{2}$ and confirms that the reaction is monooxygenation. The EI fragmentation pattern of the putative $p$-carboxybenzyl alcohol formed from $p$-toluate in the presence of ${ }^{16} \mathrm{O}_{2}$ was identical to that of authentic material (data not shown), confirming the tentative identification. TS, $p$-toluate, and 4-ethylbenzoate were converted stoichiometrically, with the consumption of 1.0 to $1.2 \mathrm{~mol}$ of $\mathrm{O}_{2}$ per mol of substrate, to $1 \mathrm{~mol}$ of the corresponding alcohol (when a standard was available). Under NADH-limiting conditions, a ratio of 0.9:1.0 for the consumption of $\mathrm{O}_{2}$ and $\mathrm{NADH}$ was obtained. We thus presume that TSMOS catalyzes the oxygenation of $1 \mathrm{~mol}$ of substrate with $1 \mathrm{~mol}$ each of $\mathrm{NADH}$ and $\mathrm{O}_{2}$ to $1 \mathrm{~mol}$ each of 


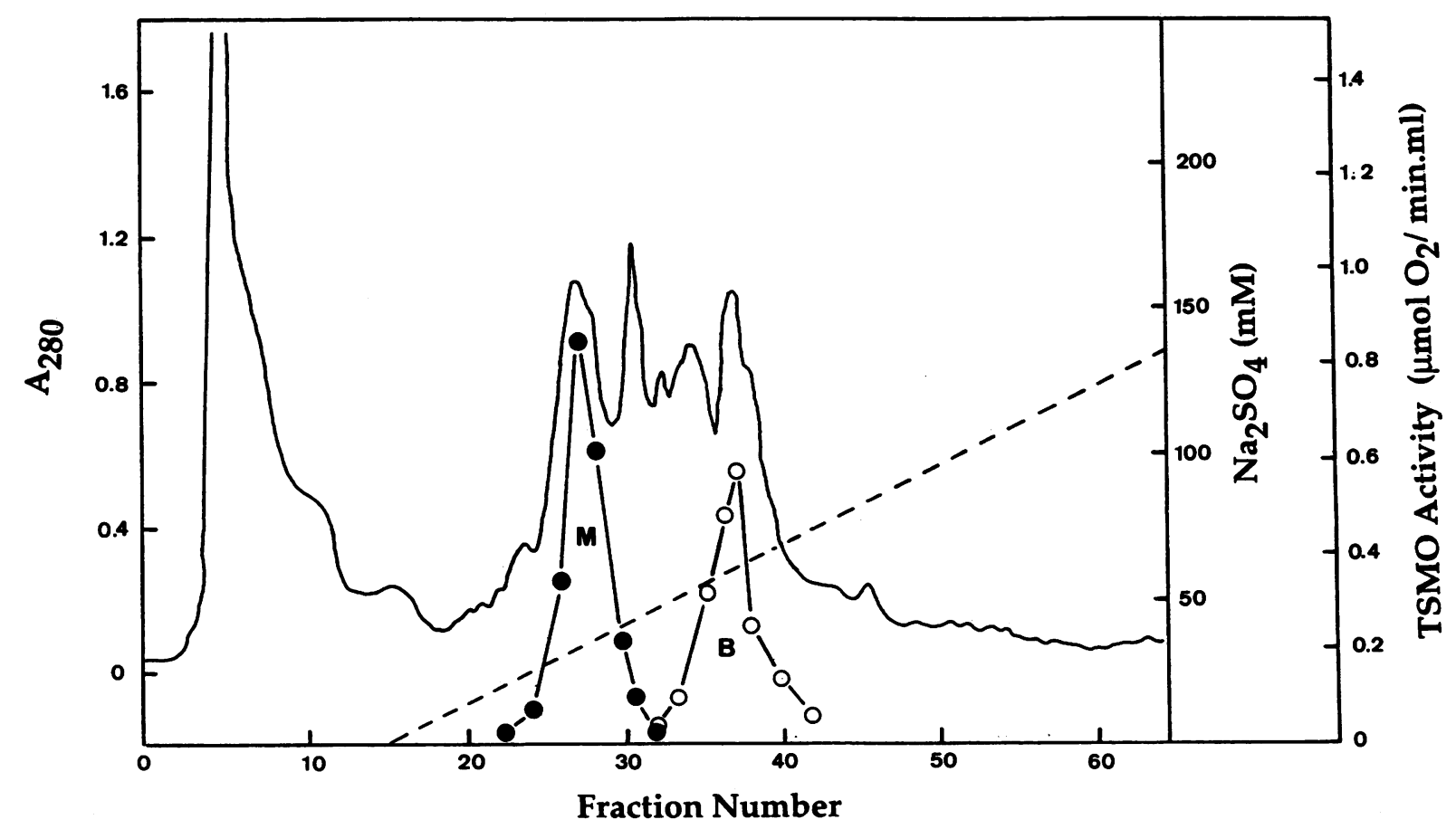

FIG. 2. Separation of the two components of TSMOS by anion-exchange chromatography. Proteins were eluted with an $\mathrm{Na}_{2} \mathrm{SO}_{4} \mathrm{gradient}$ $(---)$. Component M (oxygenase) (O) was located by measuring the TSMOS activity of fractions in assay mixtures containing $50 \mu \mathrm{g}$ of crude component B (fraction no. 37). Component B (reductase) (O) was located by measuring the TSMOS activity of fractions in assay mixtures containing $80 \mu \mathrm{g}$ of crude component M (fraction no. 26). Protein was monitored as $A_{280}(-)$ ).

the alcohol, $\mathrm{NAD}^{+}$, and $\mathrm{H}_{2} \mathrm{O}$. The alcohol was not subject to further transformation by TSMOS.

4-Ethylbenzoate was oxygenated to a more polar product with a UV spectrum similar to that of 4-carboxybenzyl alcohol (Table 4). The PCI mass spectrum showed a proto-

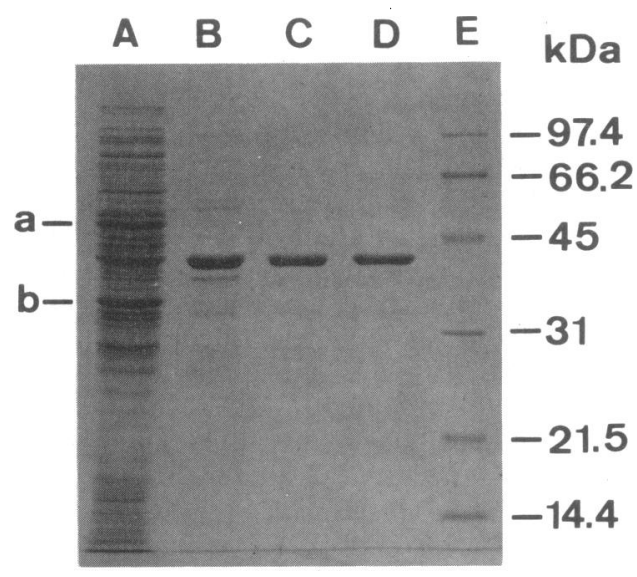

FIG. 3. SDS-PAGE of different steps during the purification of component $\mathbf{M}$ of TSMOS. Proteins were detected by staining with Coomassie brilliant blue. Lanes: A, crude extract ( $15 \mu \mathrm{g}$ of protein); $B$, crude component $M$ after the Mono $Q$ step (4 $\mu \mathrm{g})$; $C$, component $M$ after the phenyl-Superose step $(2 \mu \mathrm{g}) ; \mathrm{D}$, purified enzyme after gel filtration $(2.5 \mu \mathrm{g}) ; \mathrm{E}$, protein markers (approximately $0.3 \mu \mathrm{g}$ each). In lane $A$, the locations of the bands corresponding to the oxygenase component of PSBDOS (a) and reductase B (b) are indicated (22). nated molecular ion at $m / z 167\left[(\mathrm{M}+\mathrm{H})^{+}\right]$, consistent with a 4-carboxyphenyl ethanol. Whether the C-1 or the C-2 carbon of the ethyl substituent was hydroxylated [forming either 1-(4-carboxyphenyl)- or 2-(4-carboxyphenyl)-ethanol] could not be definitively determined, because no reference compound was available (Table 4). Preliminary results obtained from EI fragmentation spectra did not favor hydroxylation at the terminal methyl group, because an ion at $\mathrm{m} / \mathrm{z}$ $151\left[\left(\mathrm{M}-\mathrm{CH}_{3}\right)^{+}\right]$was observed.

TABLE 2. Amino acid composition of component M of TSMOS

\begin{tabular}{|c|c|}
\hline Amino acid $^{a}$ & $\begin{array}{l}\text { No. of residues/ } \\
\text { enzyme subunit }\end{array}$ \\
\hline 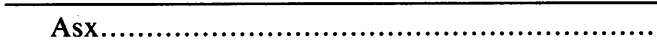 & 37.0 \\
\hline 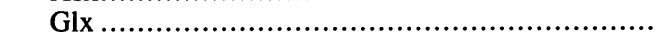 & 36.2 \\
\hline Ser ............... & 12.2 \\
\hline 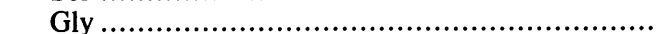 & 26.4 \\
\hline His & 10.4 \\
\hline 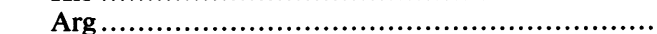 & 23.9 \\
\hline Thr & 18.9 \\
\hline Ala & 29.1 \\
\hline Pro & 24.6 \\
\hline 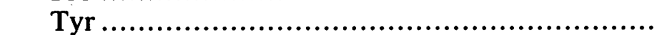 & 6.9 \\
\hline Val & 14.5 \\
\hline Met & 3.0 \\
\hline Ile …1 & 15.9 \\
\hline Leu & 28.9 \\
\hline Phe & 10.5 \\
\hline Lys & 16.7 \\
\hline
\end{tabular}

${ }^{a}$ Trp and Cys were not determined.

$b$ The values were calculated on the basis of a molecular weight of 43,000 . The data represent the means of two determinations. 


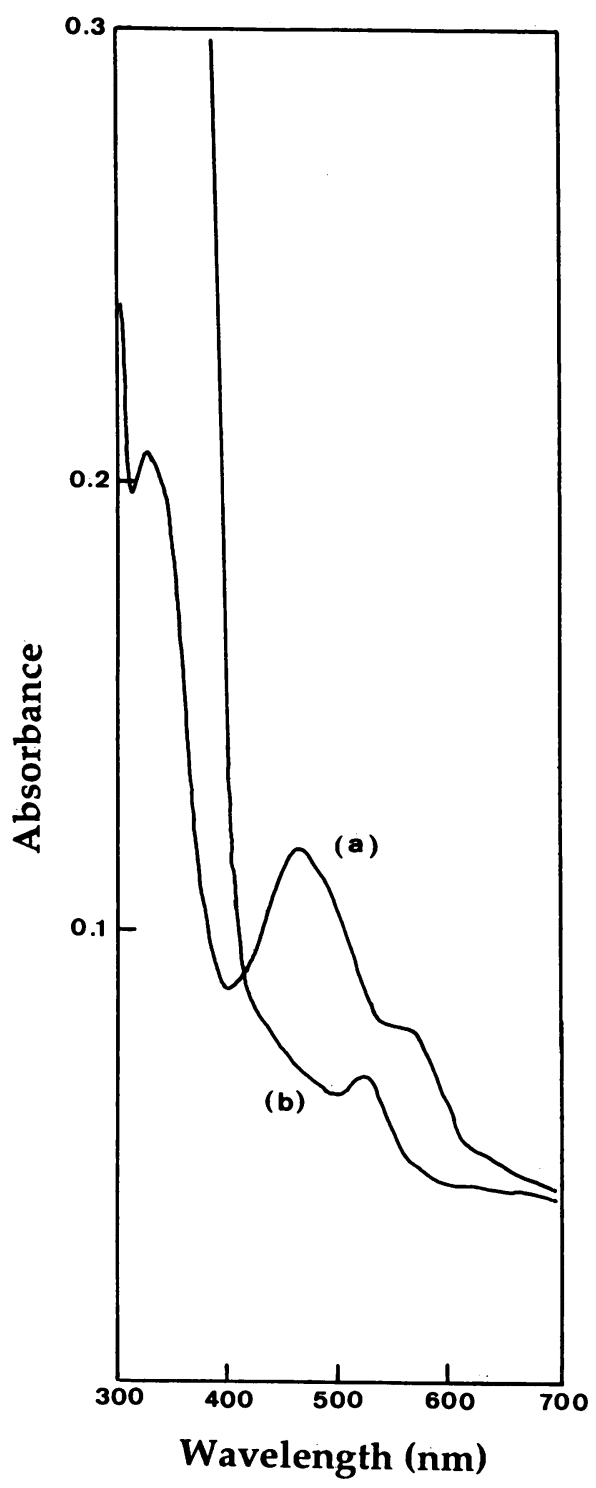

FIG. 4. Absorption spectra of component $M$ of TSMOS. (a) Purified component $\mathrm{M}(0.8 \mathrm{mg} / \mathrm{ml})$ in $20 \mathrm{mM}$ potassium phosphate buffer (pH 7.0) containing $1 \mathrm{mM}$ dithiothreitol. (b) Same sample after reduction with sodium dithionite $(1 \mathrm{mg} / \mathrm{ml})$. The same spectrum was obtained when the enzyme was reduced with $50 \mu \mathrm{g}$ of purified reductase $B$ and $0.2 \mathrm{mM}$ NADH instead of dithionite. We suspect that the presence of dithionite or NADH masked the features of the spectrum at wavelengths below $400 \mathrm{~nm}$.

TSMOS also oxygenated 4-methoxybenzoate, resulting in $\mathrm{O}$ demethylation (Table 4). In contrast, apolar methyl aromatic and aliphatic compounds ( $p$-xylene, toluene, and propane) were not substrates for TSMOS. Similarly, some sulfonated or carboxylated aromatic compounds, e.g., terephthalate and PSB, were not substrates (Table 4). Several compounds caused significant, substrate-dependent oxygen uptake with TSMOS but were apparently not transformed (Table 4). This phenomenon is referred to as uncoupling of the electron flow (17) and seems to be common in twocomponent oxygenases (e.g., 2, 3). The oxygen consumed by this process is apparently liberated as $\mathrm{H}_{2} \mathrm{O}_{2}$, because
TABLE 3. Data from UV-visible spectra of oxygenase components of different multicomponent oxygenases

\begin{tabular}{|c|c|c|c|c|c|c|}
\hline \multirow{3}{*}{$\begin{array}{c}\text { Substrate for } \\
\text { oxygenase }\end{array}$} & \multicolumn{5}{|c|}{ Wavelength $(\mathrm{nm})^{a}$} & \multirow{3}{*}{$\begin{array}{l}\text { Source or } \\
\text { reference }\end{array}$} \\
\hline & \multicolumn{3}{|c|}{ Oxidized form } & \multicolumn{2}{|c|}{ Reduced form } & \\
\hline & $\operatorname{Max}_{1}$ & $\operatorname{Max}_{2}$ & $\operatorname{Max}_{3}$ & $\operatorname{Max}_{1}$ & $\operatorname{Max}_{2}$ & \\
\hline TS & 330 & 462 & 560 & ND & 521 & This work \\
\hline 4-Methoxybenzoate & 325 & 455 & $570(s)$ & 412 & 518 & 5 \\
\hline PSB & 327 & 467 & 560 & 430 & 520 & 22 \\
\hline $\begin{array}{l}\text { 4-Chlorophenylace- } \\
\text { tate }\end{array}$ & 325 & 458 & $564(s)$ & 423(s) & 519 & 23 \\
\hline$o$-Phthalate & 328 & 466 & $560(s)$ & 434(s) & 517 & 2 \\
\hline Benzoate & 323 & 464 & $560(s)$ & ND & 518 & 38 \\
\hline Benzene & 326 & 450 & 550 & $410(s)$ & 524 & 8 \\
\hline Pyrazon & ND & 445 & $545(s)$ & 410 & 520 & 29 \\
\hline Naphthalene & 334 & 462 & $566(s)$ & 380 & 520 & 12 \\
\hline
\end{tabular}

${ }^{a}$ (s), shoulder; ND, not detected.

significant amounts of oxygen were formed when catalase was added to assay mixtures which contained uncoupling substrates (e.g., 4-chlorobenzoate), whereas no $\mathrm{H}_{2} \mathrm{O}_{2}$ was detected with TS or $p$-toluate as the substrate. 4-Aminobenzenesulfonate caused uncoupling, but some substrate disappearance was found, although no significant product was detected (Table 4). It seems that compounds with a structure similar to that of the original substrate can form an enzymesubstrate complex that catalyzes the activation of $\mathrm{O}_{2}$, which is not incorporated into the substrate but is liberated as hydrogen peroxide (3).

$\mathrm{Fe}^{2+}$ was essential for the optimal activity of TSMOS. The reaction rate of the purified enzyme was increased about fivefold by the addition of $\mathrm{Fe}^{2+}$ to the assay mixture, whereas the activity was only doubled when $\mathrm{Fe}^{2+}$ was added to crude extracts. We presume that some iron is lost from the protein during purification.

\section{DISCUSSION}

TSMOS is the first monooxygenase system to be isolated that initiates the degradation of a methyl aromatic compound at the methyl group. The system is composed of two components: a monomeric $36-\mathrm{kDa} \mathrm{NADH}$ oxidoreductase containing a flavin adenine mononucleotide (FMN) and a $2 \mathrm{Fe}-2 \mathrm{~S}$ center (22), which transfers electrons to the oxygenase component, apparently a multimeric iron-sulfur protein consisting of $43-\mathrm{kDa}$ subunits. The system has many similarities with the well-characterized 4-methoxybenzoate $O$-demethylase system of Pseudomonas putida (EC 1.14.99.15) (5) and with one class of two-component dioxygenases (e.g., EC 1.14.12.7) (2). Each has a monomeric, flavin adenine mononucleotide-containing reductase whose iron-sulfur center fulfills a ferredoxin function in transferring electrons from NADH to an oxygenase; $M_{\mathrm{r}} \mathrm{s}$ are 34,000 (2), $36,000(22)$, and $42,000(5)$. The oxygenase is homomultimeric, with apparently two (22), three $(5,23)$, or four (2) subunits, each with one presumed Rieske $(2 \mathrm{Fe}-2 \mathrm{~S})$ center per subunit. It is uncertain whether the oxygenase component of TSMOS is composed of three or four subunits. Catalytically, these two-component oxygenases frequently display the uncoupling indicated for TSMOS in Table 4 (2, 3). There appears to be more in common among these oxygenases than the separation in the EC systematics implies (see also Wackett et al. [35]). Multicomponent monooxygenases are found in EC 1.14.13.-, 1.14.14.-, 1.14.15.-, and 
TABLE 4. Substrate specificity of TSMOS and the products observed

\begin{tabular}{|c|c|c|c|}
\hline Substrate & $\begin{array}{c}\text { Relative } \\
\text { activity }^{a}(\%)\end{array}$ & $\begin{array}{c}\text { Identified } \\
\text { product(s) }\end{array}$ & Methods $^{c}$ \\
\hline TS & 100 & 4-Sulfobenzyl alcohol & $\mathrm{CC}$ and UV \\
\hline$p$-Toluate & 116 & 4-Carboxybenzyl alcohol & $\mathrm{CC}, \mathrm{UV}$, and $\mathrm{MS}$ \\
\hline$m$-Toluate & 38 & Product not identified & \\
\hline$o$-Toluate & 6 & & \\
\hline 4-Ethylbenzoate & 79 & 4-Carboxyphenyl ethanol ${ }^{d}$ & UV and MS \\
\hline$p$-Xylene & $\mathbf{0}$ & & \\
\hline Toluene & 0 & & \\
\hline Propane & 5 & & \\
\hline Terephthalate & $\mathbf{0}$ & & \\
\hline PSB & $\mathbf{0}$ & & \\
\hline 4-Methoxybenzoate & 54 & $\begin{array}{l}\text { 4-Hydroxybenzoate } \\
\text { HCHO }\end{array}$ & $\begin{array}{l}\text { CC and UV } \\
\text { Specific reaction }\end{array}$ \\
\hline$p$-Cresol & 10 & & \\
\hline 4-Carboxybenzyl alcohol & 10 & No transformation & \\
\hline Benzoate & 42 & No transformation & \\
\hline Benzenesulfonate & 47 & No transformation & \\
\hline 4-Hydroxybenzoate & 10 & & \\
\hline 4-Hydroxybenzenesulfonate & $\mathbf{0}$ & & \\
\hline 4-Aminobenzoate & $\mathbf{0}$ & & \\
\hline 4-Aminobenzenesulfonate & 54 & No significant transformation & \\
\hline 4-Chlorobenzoate & 12 & No transformation & \\
\hline 4-Chlorobenzenesulfonate & 28 & No transformation & \\
\hline
\end{tabular}

${ }^{a}$ Activity was measured as substrate-dependent oxygen uptake and standardized against TS as $100 \%$.

$b$ Substrate disappearance and formation of products were determined by HPLC if the relative activity was $>10 \%$. Products were identified as indicated.

c CC, cochromatography with authentic material (HPLC); UV, UV spectrometry; MS, mass spectrometry.

${ }^{d}$ Data from UV spectrum: $\lambda_{\max }, 197$ and $236 \mathrm{~nm} ; \lambda_{\min }, 214 \mathrm{~nm}$. The PCI mass spectrum showed a protonated molecular ion at $m / z 167\left[(\mathrm{M}+\mathrm{H})^{+}\right]$, and the EI mass spectrum showed a peak at, e.g., $\mathrm{m} / \mathrm{z}$ M - 45 (loss of hydroxylated side chain), consistent with either 1-(4-carboxyphenyl)-ethanol or 2-(4carboxyphenyl)-ethanol.

1.14.99.-. Whichever is appropriate, we suggest that the recommended name be "4-toluene sulfonate monooxygenase system," which catalyzes the reaction "4-toluene sulfonate $+\mathrm{NADH}+\mathrm{H}^{+}+\mathrm{O}_{2}=4$-sulfobenzyl alcohol $+\mathrm{H}_{2} \mathrm{O}$ $+\mathrm{NAD}^{+}$." The systematic name would then be "4-toluene sulfonate,NADH: oxygen oxidoreductase (methyl-hydroxylating)," and the comments should be "iron-sulfur-flavoprotein (FMN) reductase, no independent ferredoxin, homomultimeric iron-sulfur oxygenase: requires iron." TSMOS bears little resemblance to the three-component alkane $\omega$-monooxygenase of Pseudomonas oleovorans, whose oxygenase is membrane associated $(25,28)$; the three-component methane monooxygenase from Methylosinus trichosporium (13); or the microsomal cytochrome P-450containing alkane monooxygenases (6).

A limited comparison is possible with the TOL plasmidencoded xylene methyl-monooxygenase, apparently a twocomponent system (16), which has not been characterized biochemically but whose sequence ( $x y l A$ and $x y l M)$ is now available (32). Xylene monooxygenase is believed to transform not only toluene but also its product benzyl alcohol, presumably to benzaldehyde. Hopper (18) also observed the formation of aldehyde by $p$-cresol-methylhydroxylase, whose primary product is the alcohol. TSMOS, however, did not significantly transform the alcohol tested (Table 4) and is active only on polar compounds. The $M_{\mathrm{r}}$ of the TOL-encoded xylene monooxygenase $(41,500$ for the presumed oxygenase [XylM] and 37,000 for the reductase [XylA], calculated from the nucleotide sequence), are similar to those of TSMOS. However, the components of TSMOS are soluble, whereas Suzuki et al. (32) anticipated a membrane-associated oxygenase component of the TOLencoded enzyme analogous to that in the $P$. oleovorans $\omega$-monooxygenase (28). The amino acid compositions of the oxygenase components of TSMOS (Table 2), phthalate dioxygenase (2), and 4-methoxybenzoate $O$-demethylase (4) are similar, whereas the $x y l M$ gene product contains more hydrophobic amino acids (especially leucine and isoleucine), corresponding to its supposed location in the membrane. Since xylene monooxygenase is specific for apolar substrates, a location in the membrane would be understandable. TSMOS and the xylene monooxygenase system thus catalyze very similar chemical reactions and have similar $M_{\mathrm{r}} \mathrm{s}$ but are presumably very different with respect to hydrophobicity.

Reductase B of TSMOS can transfer electrons from $\mathrm{NADH}$ to a number of electron acceptors, including the oxygenase component of PSBDOS, and we purified reductase B as the reductase of PSBDOS (22). It is known that some reductases can reduce several ferredoxins (31), and we were uncertain about the correct assignment of the reductases in $C$. testosteroni T-2 (22). The evidence presented above indicates that reductase $B$ and oxygenase $M$ are induced simultaneously and independently of the oxygenase component of PSBDOS. Assuming that the native oxygenase is a tetramer and is present at $4.3 \%$ of soluble protein and that the monomeric reductase $\left(M_{r}, 36,000\right)$ represents $7.2 \%$ of soluble protein, the reductase is present in the cell in an eightfold excess over the native oxygenase. This idea is compatible with the effectively saturated oxygenase in crude extracts.

TSMOS and the 4-methoxybenzoate $O$-demethylase from $P$. putida (3) not only share similar structure and susceptibility to uncoupling, but each can also monooxygenate methyl aromatic groups and $\mathrm{O}$ demethylate. Whereas TSMOS shows a higher activity to hydroxylate $p$-toluate 
than to demethylate 4-methoxybenzoate (Table 4), the enzyme from $P$. putida has the reverse specificity (3). It seems possible that the TSMOS in $C$. testosteroni $\mathrm{T}-2$, which was isolated from enrichment cultures in TS-salts medium, did not evolve specifically to transform the xenobiotic sulfonated compound TS. Rather, it is an oxygenase with a broad substrate range for polar, $O$-methyl, and methyl aromatic compounds. Methoxy aromatic compounds are natural compounds which are widely distributed in nature as lignins (19). We suspect that TSMOS is a "natural" monooxygenase which was recruited, probably prior to the enrichment culture, into the degradative pathway of the sulfonated, xenobiotic substrate.

\section{ACKNOWLEDGMENTS}

We thank T. Vorherr and R. Falchetto, Biochemistry, ETH Zürich, Switzerland, for analyses of amino acid compositions and $\mathrm{N}$-terminal amino acids and K. Ramsteiner, Ciba-Geigy AG, Basel, Switzerland, for MS analyses. We are grateful to S. Harayama for supplying a preprint (32).

This work was supported by a grant from the Kommission zur Förderung der Wissenschaftlichen Forschung (Project 1567).

\section{REFERENCES}

1. Axcell, B. C., and P. J. Geary. 1975. Purification and some properties of a soluble benzene-oxidizing system from a strain of Pseudomonas. Biochem. J. 146:173-183.

2. Batie, C. J., E. LaHaie, and D. P. Ballou. 1987. Purification and characterization of phthalate oxygenase and phthalate oxygenase reductase from Pseudomonas cepacia. J. Biol. Chem. 262:1510-1518.

3. Bernhardt, F.-H., N. Erdin, H. Staudinger, and V. Ullrich. 1973. Interactions of substrates with a purified 4-methoxybenzoate monooxygenase system ( $O$-demethylating) from Pseudomonas putida. Eur. J. Biochem. 35:126-143.

4. Bernhardt, F.-H., E. Heymann, and P. S. Traylor. 1978. Chemical and spectral properties of putidamonooxin, the iron-containing and acid-labile-sulfur-containing monooxygenase of a 4-methoxybenzoate $O$-demethylase from Pseudomonas putida. Eur. J. Biochem. 92:209-223.

5. Bernhardt, F.-H., H. Pachowsky, and H. Staudinger. 1975. A 4-methoxybenzoate $O$-demethylase from Pseudomonas putida. Eur. J. Biochem. 57:241-256.

6. Black, S. D., and M. J. Coon. 1986. Comparative structures of P-450 cytochromes, p. 161-216. In P. R. Ortiz de Montellano (ed.), Cytochrome P-450: structure, mechanism and biochemistry. Plenum Press, New York.

7. Bradford, M. M. 1976. A rapid and sensitive method for the quantitation of microgram quantities of protein utilizing the principle of protein-dye binding. Anal. Biochem. 72:248-254.

8. Crutcher, S. E., and P. J. Geary. 1979. Properties of the iron-sulphur proteins of the benzene dioxygenase system from Pseudomonas putida. Biochem. J. 177:393-400.

9. Dagley, S. 1971. Catabolism of aromatic compounds by microorganisms. Adv. Microb. Physiol. 6:1-46.

10. Dagley, S. 1988. Microbial catabolism and the carbon cycle: a perspective, p. 3-13. In S. R. Hagedorn, R. S. Hanson, and D. A. Kunz (ed.), Microbial metabolism and the carbon cycle. Harwood Academic Publishers, New York.

11. DeFrank, J. J., and D. W. Ribbons. 1977. p-Cymene pathway in Pseudomonas putida: initial reactions. J. Bacteriol. 129:13561364.

12. Ensley, B. D., and D. T. Gibson. 1983. Naphthalene dioxygenase: purification and properties of a terminal oxygenase component. J. Bacteriol. 155:505-511.

13. Fox, B. G., W. A. Froland, J. E. Dege, and J. D. Lipscomb. 1989. Methane monooxygenase from Methylosinus trichosporium OB3b. Purification and properties of a three-component system with high specific activity from a type II methylotroph. J. Biol. Chem. 264:10023-10033

14. Gibson, D. T. 1988. Microbial metabolism of aromatic hydro- carbons and the carbon cycle, p. 33-58. In S. R. Hagedorn, R. S. Hanson, and D. A. Kunz (ed.), Microbial metabolism and the carbon cycle. Harwood Academic Publishers, New York.

15. Gibson, D. T., and V. Subramanian. 1984. Microbial degradation of aromatic hydrocarbons, p. 181-252. In D. T. Gibson (ed.), Microbial degradation of organic compounds. Marcel Dekker, Inc., New York.

16. Harayama, S., R. A. Leppik, M. Rekik, N. Mermod, P. R. Lehrbach, W. Reineke, and K. N. Timmis. 1986. Gene order of the TOL catabolic plasmid upper pathway operon and oxidation of both toluene and benzyl alcohol by the $x y l A$ product. J. Bacteriol. 167:455-461.

17. Hayaishi, O. 1974. Molecular mechanisms of oxygen activation, p. 1-25. Academic Press, Inc., New York.

18. Hopper, D. J. 1988. Properties of $p$-cresol methylhydroxylases, p. 247-258. In S. R. Hagedorn, R. S. Hanson, and D. A. Kunz (ed.), Microbial metabolism and the carbon cycle. Harwood Academic Publishers, New York.

19. Kirk, T. K. 1984. Degradation of lignin, p. 399-437. In D. T. Gibson (ed.), Microbial degradation of organic compounds. Marcel Dekker, Inc., New York.

20. Laemmli, U. K. 1970. Cleavage of structural proteins during the assembly of the head of bacteriophage T4. Nature (London) 227:680-685.

21. Locher, H. H., T. Leisinger, and A. M. Cook. 1989. Degradation of $p$-toluenesulphonic acid via sidechain oxidation, desulphonation and meta ring cleavage in Pseudomonas (Comamonas) testosteroni T-2. J. Gen. Microbiol. 135:1969-1978.

22. Locher, H. H., T. Leisinger, and A. M. Cook. 1991. 4-Sulphobenzoate 3,4-dioxygenase: purification and properties of a desulphonative two-component enzyme system from Comamonas testosteroni $\mathrm{T}-2$. Biochem. J. 274:833-842.

23. Markus, A., D. Krekel, and F. Lingens. 1986. Purification and some properties of component A of the 4-chlorophenylacetate 3,4-dioxygenase from Pseudomonas species. J. Biol. Chem. 261:12883-12888.

24. Nozaka, J., and M. Kusunose. 1968. Oxidation of $p$-xylene and toluene by cell-free enzyme preparations of Pseudomonas aeruginosa. Agric. Biol. Chem. 32:1033-1039.

25. Peterson, J. A., D. Basu, and M. J. Coon. 1966. Enzymatic $\omega$ oxidation. I. Electron carriers in fatty acid and hydrocarbon hydroxylation. J. Biol. Chem. 241:5162-5170.

26. Reeve, C. D., M. A. Carver, and D. J. Hopper. 1990. Stereochemical aspects of the oxidation of 4-ethylphenol by the bacterial enzyme 4-ethylphenol methylenehydroxylase. Biochem. J. 269:815-819.

27. Ribbons, D. W. 1971. Requirement of two protein fractions for $O$-demethylase activity in Pseudomonas testosteroni. FEBS Lett. 12:161-165.

28. Ruettinger, R. T., S. T. Olson, R. F. Boyer, and M. J. Coon. 1974. Identification of the $\omega$ hydroxylase of Pseudomonas oleovorans as a nonheme iron protein requiring phospholipid for catalytic activity. Biochem. Biophys. Res. Commun. 57:10111017.

29. Sauber, K., C. Fröhner, G. Rosenberg, J. Eberspächer, and F. Lingens. 1977. Purification and properties of pyrazon dioxygenase from pyrazon-degrading bacteria. Eur. J. Biochem. 74:89-97.

30. Stucki, G., R. Gälli, H.-R. Ebersold, and T. Leisinger. 1981 Dehalogenation of dichloromethane by cell extracts of $\mathrm{Hy}$ phomicrobium DM2. Arch. Microbiol. 130:366-371.

31. Subramanian, V., T.-N. Liu, W.-K. Yeh, M. Narro, and D. T. Gibson. 1981. Purification and properties of NADH-ferredoxin $_{\text {TOL }}$ reductase, a component of toluene dioxygenase from Pseudomonas putida. J. Biol. Chem. 256:2723-2730.

32. Suzuki, M., T. Hayakawa, J. P. Shaw, M. Rekik, and S. Harayama. 1991. Primary structure of xylene monooxygenase: similarities to and differences from the alkane hydroxylation system. J. Bacteriol. 173:1690-1695.

33. Thurnheer, T., T. Köhler, A. M. Cook, and T. Leisinger. 1986. Orthanilic acid and analogues as carbon sources for bacteria: growth physiology and enzymic desulphonation. J. Gen. Microbiol. 132:1215-1220.

34. Thurnheer, T., D. Zürrer, O. Höglinger, T. Leisinger, and A. M. 
Cook. 1990. Initial steps in the degradation of benzene sulfonic acid, 4-toluene sulfonic acid, and orthanilic acid in Alcaligenes sp. strain 0-1. Biodegradation 1:55-64.

35. Wackett, L. P., L. D. Kwart, and D. T. Gibson. 1988. Benzylic monooxygenation catalyzed by toluene dioxygenase from Pseudomonas putida. Biochemistry 27:1360-1367.

36. Winkler, P. C., D. D. Perkins, W. K. Williams, and R. F Browner. 1988. Performance of an improved monodisperse aerosol generation interface for liquid chromatography/mass spectrometry. Anal. Chem. 60:489-493.

37. Worsey, M. J., and P. A. Williams. 1975. Metabolism of toluene and xylenes by Pseudomonas (putida (arvilla) mt-2: evidence for a new function of the TOL plasmid. J. Bacteriol. 124:7-13.

38. Yamaguchi, M., and H. Fujisawa. 1982. Subunit structure of oxygenase component in benzoate-1,2-dioxygenase system from Pseudomonas arvilla C-1. J. Biol. Chem. 257:12497-12502. 